\title{
AN ASSESSMENT OF THE VARIOUS MITIGATION STRATEGIES TO COMBAT DESERTIFICATION IN JIBIA AND KAITA LOCAL GOVERNMENT AREAS OF KATSINA STATE
}

\author{
Richard Sunday Thlakma ${ }^{1 *}$ and Omale Eche John ${ }^{2}$ \\ ${ }^{1}$ Department of Geography, Faculty of Humanities, Management and Social Sciences, \\ Federal University of Kashere, PMB 0182, Gombe State, Nigeria \\ ${ }^{2}$ Department of Geography, Ahmadu Bello University Zaria, Nigeria \\ Email: profsrthlakma@gmail.com
}

Received 7 April 2019/ Revised 19 July 2019/ Accepted 22 July 2019/ Published 2 August 2019

\begin{abstract}
This study was conducted on an assessment of the various mitigation strategies to combat desertification in Jibia and Kaita Local Government Areas of Katsina State, Nigeria. The data use includes Satellite imageries for the study such as landsat MSS of 1976, landsat TM of 1987, SPOT XS of 1995 and landsat ETM of 2006 as well as structured questionnaires. Sixty close ended copies of the Questionnaire were administered in the study. Purposive sampling method of administering questionnaires was adopted. The percentages land mass covered for each of these variables was determined and estimated in $\mathrm{M}^{2}$. literature was obtained from various agencies which were responsible for desertification control in Katsina state. It was found from the reserved forest that in 1976 the percentage of reserved forest was $2.57 \%$. In 1987 however, it increased by $73.9 \%$ to $76.47 \%$. By 1995 , it declined by $9.42 \%$ to $67.05 \%$ and further declined by $0.52 \%$ in 2006 . Effort to combat desertification through the use of reserved forest has been quite significant over the years. Also, noticed was a declined in shelter belt from $5.91 \%$ in 1987 to $1.097 \%$ in 1995 and a shot up to $7.39 \%$ in 2006 . About $37 \%$ of the respondent opined that the deforestation leads to the disappearance of trees while $33 \%$ pinioned that it leads to reduction on agricultural productivity. The major strategy adopted to combat desertification is tree planting as supported by $88 \%$ of the respondents. It found that desertification as major environmental problem of the study area has reduced drastically from $43.34 \%$ in 1976 to $1.29 \%$ in 2006 . It was also revealed from this study that some organizations such as European Economic Community/Katsina State government EEC/KTSG, Katsina Afforestation Project Unit KTAPU and Local Government Councils are the major agencies that are responsible for mitigating desertification in the study area.
\end{abstract}

Keywords: Desertification, Mitigation, Afforestation, Shelterbelt and Satellite image

\section{Introduction}

Campbell (1986) and Mortimore (1989) define desertification as a process of sustained land degradation (loss of primary production) that results in the inability of the environment to sustain the demands being made upon it by socio - economic systems at 
existing levels of technology and economic development and under prevailing climatic conditions especially drought. This definition reflects the situation in Jibia and Kaita Local Government Areas of Katsina State which is the study area in which the poor socio-economic activities led the residents to engaged in deforestation which led to the increase in deforestation and drought and also led to increase in micro climate of the study area leading to thereby increasing the rate and magnitudes of deforestation in the Jibia and Kaita Local Government Areas.

Deforestation and the degradation of other vegetation, particularly near the margins of deserts have caused once fertile, vegetated land to become barren in a process called desertification. It has been suggested that desertification should be regarded as an extreme form of land degradation occurring where vegetation cover falls below 35 percent on a long term basis (Binns 1990). Although desert boundaries have shifted over time, deserts have always characterized the earth's subtropical zones. Global patterns of air circulation dictates that the subtropics are regions of subsiding air. When air subsides, it cools down and its capacity to hold moisture decreases, so inhibiting the formation of rain. This accounts for a prevalence of dry climates between latitudes $15^{\circ}$ and $30^{\circ}$ 'north and south of the equator. However, these dry climates are extended into other latitudes and their patterns complicated by additional factors, such as distance from the rain-supplying oceans, seasonal high-pressure zones of large continental areas linked with monsoon systems, or the presence of mountain barriers over which air spills on the Leeward side. Thus creating rain shadows, (United Nations Conference on Desertification Nairobi, 1977).

The first alarm on the south ward movement of the Sahara Desert into Nigeria was raised by Stebbing in (1935) partly in response to other environmental deterioration and desert encroachment. An Anglo-French forestry commission in 1937 investigated the evidence of desertification in the northern part of Nigeria, and found no evidence to support the report. However, this report created some concern in the colonial emirate. They embarked on tree planting to stop the southward drift of Sahara Desert, as far back as the 1940s.

Generally, areas most severely affected by desertification in Nigeria are the semi-arid areas lying roughly north of Latitude $12^{\circ} \mathrm{N}$, and these fall within the Sudan and Sahel zones of Nigeria (Sagua, et al, 1987). The extent and severity of desertification in Nigeria is not fully established neither is the rate of its progression properly documented. However, it is generally agreed that it is by far the most pressing 
environmental problem in the northern part of the country. The visible sign of the phenomenon is the gradual shift in vegetation from bushes and occasional trees to grass and bushes and in the final stages, expansive areas of desert like sand (Ariyo, et al 2005). The United Nation Conventions to combat Desertification has called for actions involving International cooperation and a partnership approach. It focuses on improving land productivity, the application of land conservation and sustainable management and water resources, (UNDPI, 1997).

According to the Federal Government of Nigeria (FOS, 1999) estimates, between $50 \%$ and $75 \%$ of Bauchi, Borno, Gombe, Jigawa, Kano, Katsina, Kebbi, Sokoto, Yobe, and Zamfara states are being affected by desertification. These states, with a population of about 35 million people account for about $35 \%$ of the country's total land area.

Table 1. Spread of desertification in Nigeria (FOS, 1999).

\begin{tabular}{ccc}
\hline & Land area $(\mathrm{km} 2)$ & \% of Nigeria landmass affected \\
\hline Bauchi/Gombe & 64,605 & 6.99 \\
Borno & 70,890 & 7.67 \\
Yobe & 45,502 & 4.93 \\
Kano & 20,131 & 2.18 \\
Jagawa & 23,154 & 2.51 \\
Katsina & 24,192 & 2.62 \\
Sokoto/Zamfara & 65,735 & 7.12 \\
Kebbi & 36,800 & 3.98 \\
\hline
\end{tabular}

In addition, seven adjacent states to the south are reported to have about $10 \%$ to $15 \%$ of their land areas threatened by processes of desertification. It is estimated that the country is currently losing about 351,000 hectares of its landmass to desert conditions annually, and such conditions are estimated to be advancing south wards at the rate of about $0.6 \mathrm{~km}$ per year (Ariyo et al 2005). In the absence of concrete remedial and mitigative measures, it is estimated that the total cost of environmental degradation in Nigeria would amount to about U.S. $\$ 5.110$ billion per annum, 73\% of which will result from land degradation alone (including desertification and erosion (Ariyo et al., 2005).

Njeru, (2009) reported that sand dune stabilization is often done through the use of shelterbelt, woodlot and wind breaks. Wind breaks are made from trees and bushes and are used to reduce water erosion and evapotranspiration. They were widely encouraged by Development Agencies from the Middle East. Also, the spraying of petroleum and Nano clay over semi-arid crop land. This is often done in areas where 
either petroleum or Nano clay obtainable for example in Iran. In both cases the application of the materials coats seedlings to prevent moisture loss and prevent them from being blown away. Community participation in controlling desertification is also encouraged by the United Nation Convention to Combat Desertification which calls for a bottom up participatory approach in identifying, implementing, monitoring and evaluating projects that combat desertification and mitigate the effect of drought. Project should be initiated and managed with maximum participation of local communities including women, youth, poor farmers, and pastoralists. The UNCCD offers local communities a very wide range of opportunities based on local communities, local circumstances, tradition, culture, norms, knowledge, and aspiration, (Msafirri, 2009).

Katsina state is one of the states affected by desertification. It has both environmental and socio economic consequences. According to KTARDA (2006). all the farmlands within Kwangwalam area of Katsina state are severely subjected to strong northeasterly harmattan wind, and sheet erosion, which sweeps the top soils, leaving the land bare and unproductive for agricultural purposes. Murtala (2003) reported that desertification in Katsina state has led to the reduction in the productivity of the land to the bearest minimum, thus eliminating the already meagre food and water resources for livestock.

Bala (2003) reports that Katsina state has many desertification control projects.These include EEC/KTSG, Katsina Arid Zone Programme, FGN/World Bank Assisted Afforestation Project, Katsina state committee on drought and desertification control, Federal Department of Forestry, Katsina State Ministry of Agriculture, and Katsina State Afforestation Project Unit, KTPU. Their major aim is afforestation, and land management to combat the menace of desertification.

Despite global concern about desertification and other forms of land degradation (Soil quality decline, huge acres of land lost due to soil erosion, Fertile soils erode away, overgrazing by animals such as cattle, goats, sheep, feed on the grass amongst others) and many years of efforts and investment made for prevention, cure or rehabilitation, the processes of land degradation persist. There are a variety of existing and potential prevention and mitigation strategies for the various desertification and land degradation process, such as physical measures and adaptation strategies integrating changing social, economic, institutional and policy factors. The mitigation of water-related land degradation is crucial in arid and semi-arid areas which are very prone to desertification 
and successful measures invariably depend on an improvement of water storage in the soil (Njeru, 2005).

An appraisal of desertification strategies is important for the purpose of desert management in Katsina state and other parts of Nigeria. It is on this background the research aimed at assessment of the various mitigation strategies to combat desertification in Jibia and Kaita Local Government Areas of Katsina State by identify the various mitigation strategies employed in the LGAs and assessing the degree of success of the mitigation strategies adopted for mitigating the desertification problem in the LGAs.

The study area covers Jibia and Kaita Local Government Areas. These Local Government Areas are located adjacent to each other. They are located approximately between latitudes $12,{ }^{0} 45 \mathrm{~N}$ and $13,{ }^{0} 15 \mathrm{~N}$ and longitudes $7,{ }^{0} 00 \mathrm{E}$ and $8^{0}, 30 \mathrm{E}$. The area is located in the extreme north western part of Katsina State as show in Figure 1.

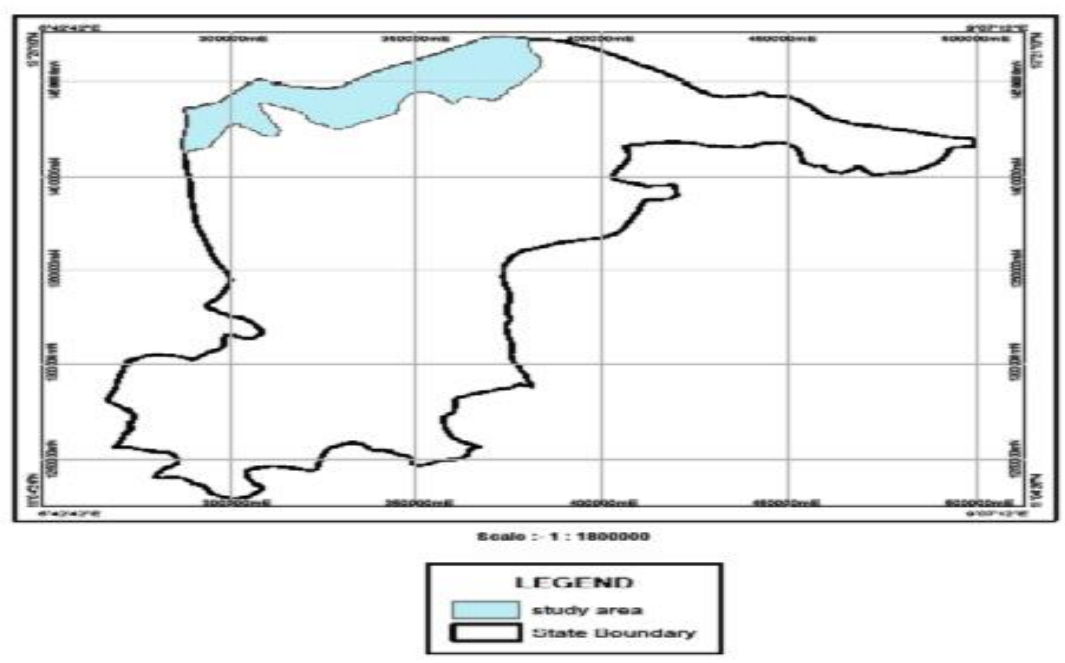

Figure 1. Map of the Study Area

The climate is seasonally wet and dry. It is dominated by two air masses. These are the rain bearing south-westerly winds and the cold, dry and dusty north-easterly winds, locally known as the "harmattan." At different times of the year, when one or the other winds prevails, the area experiences either rainfall or dry harmattan depending on the advance or retreat of the other (Nyong and Kanarogou, 1999).

The vegetation here is Sudan savannah type.It it is composed of trees scattered over an expanse of grassland. The trees are usually characterized by broad canopies e.g the baobab with large trunk.It is taller and larger than the others species or types found here.It also includes various types of acacias (Nilofica, Albida and Seyal). Others are 
Neem (Azadrita indica) etc and various types of scattered shrubs such as plastima Cassia Sigrana, occasionally forming woodlot. Most of these trees are xylophytic in nature i.e the ability to resist drought conditions, this is through having longroots, leathery leaves and tiny leaves, as well as development of spines to reduce excessive transpiration. The drought resistant plants do not shed their leaves, but other trees shed their leaves during the dry season.

The blades of the grasses wither and dry off during the dry season. Their underground stems develop new roots during wet season. Grasses in the area hardly grows up to $1 \mathrm{~m}$ at maturity. Pasture in the area is very low and grazing fields are diminishing due to intensive cultivation by the growing population and shrubs usually dry off in the dry season leaving the soil bare, man-made plantations forms a significant portion of vegetation in this area. Shelter belts woodlots and wind breaks are all found in the area (Shittu, 1999).

The study area falls within the Chad formation which is made up of sedimentary rocks of Cretaceous origin. The relief of the area is of the lower Chad plains. The relative relief falls within the average of about 15 to 20 metres, the landform in the study area is sandy plains where great sand sheets occupy most of the area. However, it is not uncommon to find deposits of sand dunes of varying degrees especially when you move towards Daddara Kusa, Kaga villages in Jibia local government Area and Dankama, Duma, Jiki Gisgerewa villages in Kaita Local government area northwards. The dunes are formed from the deposition of eroded materials carried along by strong winds from across the Sahara Desert, especially during the dry season, (Shittu, 1999).

The soil consists of mostly unconsolidated sediments which are predominantly sandy, silt to sandy loam, it is brown or reddish brown in nature. This type of soil is formed from the deposition of eroded materials over sedimentary formation. They are less acidic and well drained, with fairly low clay content.

Jibia Local Government area has a population of 167,435 people, while Kaita Local Government Area has a population of 182,405(National Population Commission 2006). The people of Jibia and Kaita Local Government Areas are predominantly Hausa and Fulani living together, Majority of the inhabitants of the areas are farmers, (Subsistence). They also keep animals; almost every family keeps grazing animals like cattle, Goats, and sheep. These are usually moved by herders from one place to the other in search of pastures especially during the dry season. Some owners of these animals 
move then to areas south of Katsina state especially the middle belt region of the country during the dry season in search of past.

\section{The Methods}

Identify the various mitigation strategies adopted to curb desertification in the study area. This was determined from the satellite imageries, LANDSAT MSS of 1976, 50m, LANDSAT TM 30m of 1987, 1995 SPOT XS20m and 2006 LANDSAT ETM. These imageries also covered four decades with one for each decade. The percentages land mass covered for each of these variables was determined and estimated in $\mathrm{M}^{2}$. The imageries used to achieve these objectives, where analyzed by visual interpretation of the imageries. Digital image processing of the satellite data and analysis of the stated objectives of the study were carried out using the basic software's. Earth Resource Data Acquisition System, ArcGIS 10.0 software. These digital data on CD ROMS were procured from Federal Department of Agriculture and Land Resources, Livestock House Mando, in Kaduna and the National Space Research and Development Agency, Abuja.

Assessing the degree of success for mitigation strategies adopted for mitigating the desertification problem in the LGAs. This was determined from structured questionnaire, which was administered to respondents. Sixty close ended copies of the Questionnaire were administered in the study. Purposive sampling method of administering questionnaires was adopted. In addition to the data obtained from the satellite imageries and questionnaire administered, literature was also obtained from various agencies which were responsible for desertification control in Katsina state. Some of the agencies are European Economic community EEC/Katsina state Government (EEC/KTGS), Katsina State Agricultural and Rural Development Authority (KTARDA and the afforestation Project unit (KTAPU). Descriptive statistics such as Tables, mean, graphs, percentages, frequency, pie chart, bar graphs and line graphs were used for data analysis and presentation.

\section{Results and Discussion}

\subsection{Identify the Various Strategies Adopted to Combat Desertification}

Available statistics show that the strategies used to combat desertification in the study areas are: through reserved forests, reservoirs for irrigation purposes in other to 
maintain and sustain the soil moisture contents so as to reduced decline in soil fertility, tree planting in the form of Shelter belts, Woodlots, trees on boundary, the use of vertiver grasses, natural tree regeneration, community and private woodlots (i.e. wind breaker). From the satellite imagery, the estimated land mass (in meter square) was estimated for each of the strategies in four decades: 1976, 1987, 1995 and 2006. Percentages and line graphs were then used to analyse the data. The data extracted are presented in Table 2.

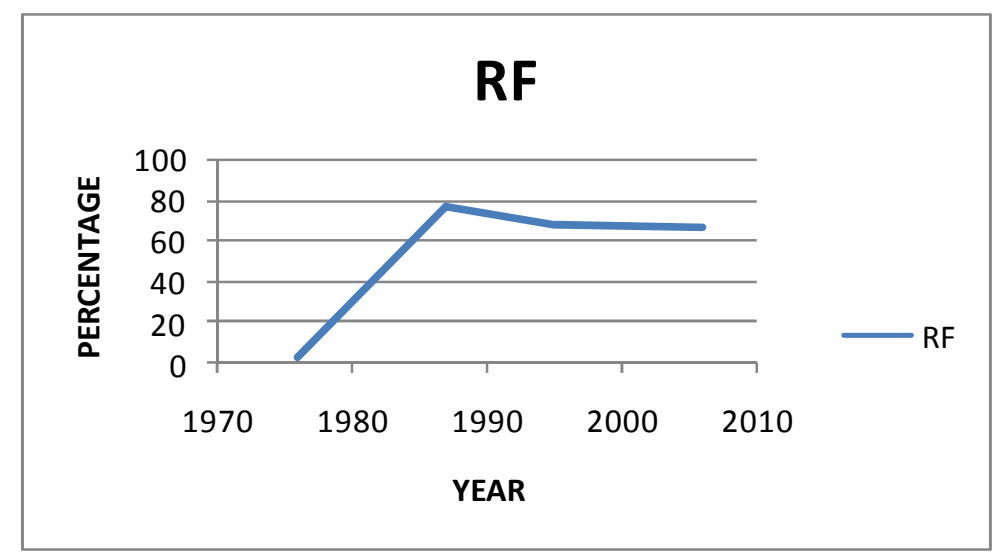

Figure 3. Trend of Reserved Forest Area in the Study Area (1976 - 2006) Source: Author's Analysis 
Richard Sunday Thlakma and Omale Eche John/GEOSI Vol 4 No 2 (2019) 124-145

Table 2. Afforestation Statistics in Jibia and Kaita LGA

\begin{tabular}{|c|c|c|c|c|c|c|c|c|c|c|}
\hline Year & $\begin{array}{l}\text { Reserved Forest } \\
\text { (RF) in } \mathrm{M}^{2}\end{array}$ & $\begin{array}{l}\mathrm{RF} \\
(\%)\end{array}$ & $\begin{array}{l}\text { Reservoir } \\
(\mathrm{R}) \text { in } \mathrm{M}^{2}\end{array}$ & $\mathrm{R}(\%)$ & $\begin{array}{c}\text { Tree Planting e.g } \\
\text { woodlots, Natural } \\
\text { regeneration, trees } \\
\text { on farmland (TP) in } \\
\mathrm{M}^{2}\end{array}$ & $\mathrm{TP}(\%)$ & $\begin{array}{l}\text { Shelter Belt } \\
(\mathrm{SB}) \text { in } \mathrm{M}^{2}\end{array}$ & $\begin{array}{l}\text { SB } \\
(\%)\end{array}$ & Afforestation total & Total \\
\hline 1976 & 1276564.019867 & 2.57 & & & 48331705.96 & 97.43 & & & 49608269.88 & 100.0 \\
\hline 1987 & 164925844.03604 & 76.48 & & & 49446684.16 & 22.93 & 1276564.02 & 5.91 & 215649092.2 & 100.0 \\
\hline 1995 & 193411475.14774 & 67.05 & 23312072.56 & 8.08 & 68566593.32 & 23.77 & 3164720.65 & 1.10 & 288454861.6 & 100.0 \\
\hline 2006 & 199901900.712514 & 66.54 & 22958856.09 & 7.64 & 75342483.75 & 25.08 & 2220605.66 & 7.39 & 300423846.2SSSSSSS & 100.0 \\
\hline
\end{tabular}

Source: Author's Analysis 


\subsubsection{Forest Reserve}

It was found from the reserved forest that in 1976 the percentage of reserved forest was $2.57 \%$. In 1987 however, it increased by $73.9 \%$ to $76.47 \%$. By 1995 , it declined by $9.42 \%$ to $67.05 \%$. By 2006 it further declined by $0.52 \%$. The decline in forest reserve is small compared to the much increase observed. Effort to combat desertification through the use of reserved forest has been quite significant over the years. The line graph, showing the trend of reserved forest from 1976 to 2006 (in decades) is shown above. These changes are seen on Figures 3, 4, 5 and 6, this is found in the coloration and sizes of the area coverage of the forest reserve areas, shown on the map, it is from these maps that the statistic for the area coverage of reserved forest where determined.

\subsubsection{The use of Reservoirs for Irrigation Purposes}

The result for reservoirs for irrigation also revealed that it declined in size due to decrease in irrigation farming, high level of deforestation, overgrazing by animals, over cultivation of lands for agricultural purposes and increase in climate change in the study area between 1995 and 2006 by $0.44 \%$. The decline in the area coverage of water bodies (Jibia dam in particular) between 1995-2006 was as a result of various purposes, the dam is used for e.g domestic purposes. The shrinking size also is attributable to the building up of sediments in the dam. Vegetation is also gradually taking over the immediate surrounding of the dam, thereby reducing its size, the shrinking size of the dam may also be attributed to the amount of rainfall, of the particular year the imagery was taken, the amount of rainfall may be small. The dam however has played a very vital role in the irrigation of the vegetation of its immediate surroundings. This has helped to reduce desertification in the area drastically.

Figures 5 and 6 shows the dam with a little decrease in the area coverage of the dam, in plates 1 and 2 are different views of the dam which is used for irrigation purposes and also supply water for shelter belts, woodlots, etc. Figure 7 shows a decrease in the area coverage of the dam. 


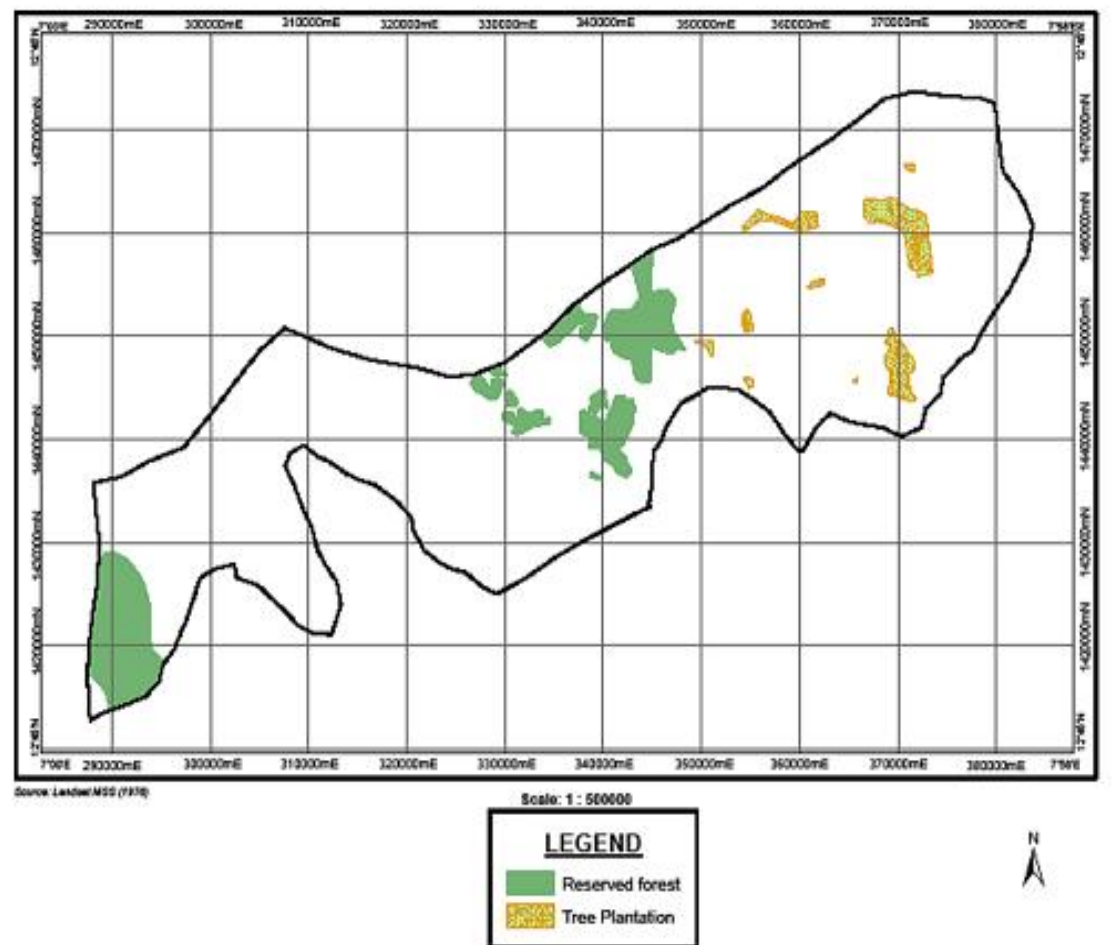

Figure 3. Afforestation in Jibia and Kaita Local Government Areas of Katsina State (1976)

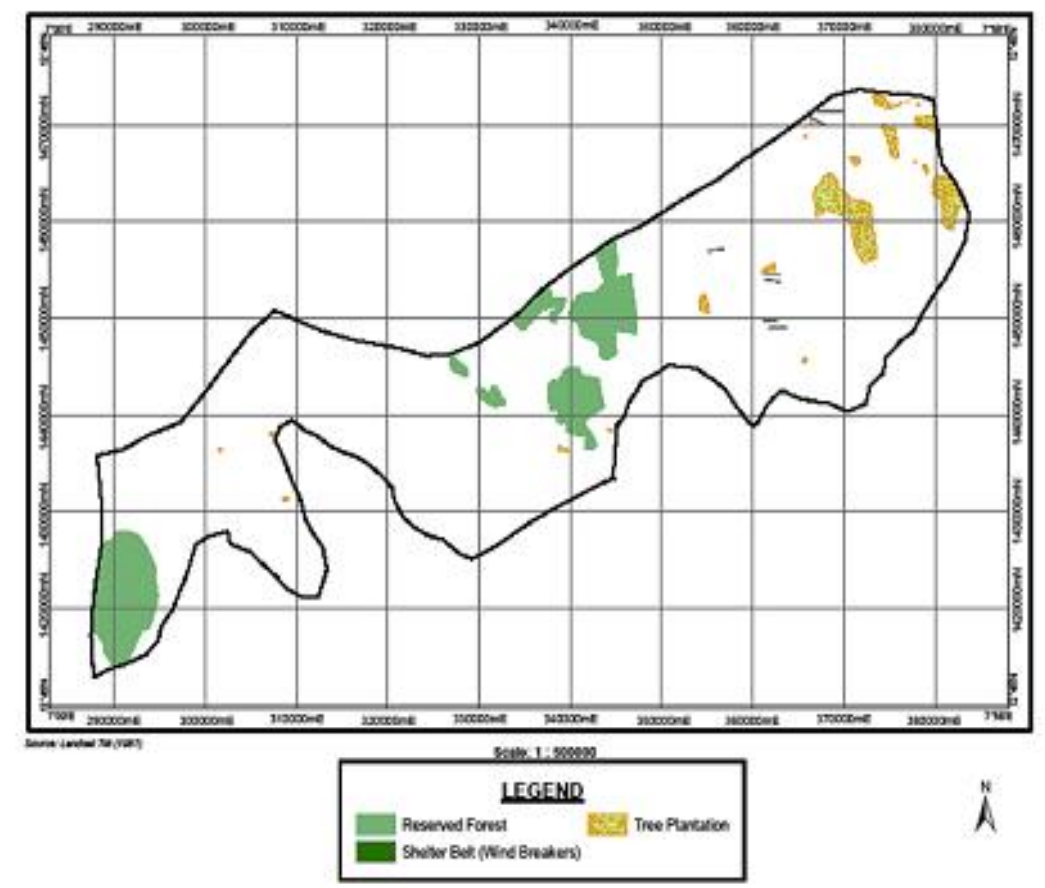

Figure 4. Afforestation in Jabia and Kaita LGA of Kastina State (1987) 


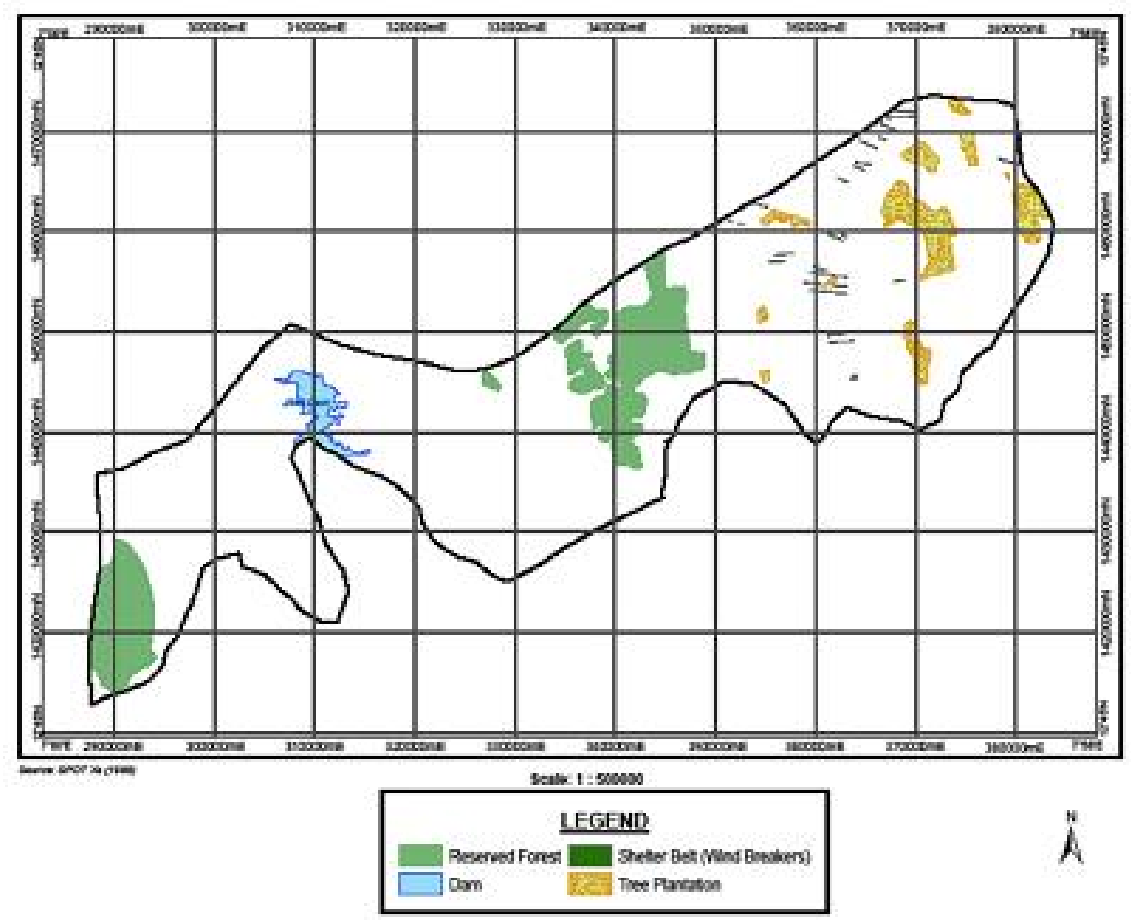

Figure 5. Afforestation in Jabia and Kaita LGA of Kastina State (1995)

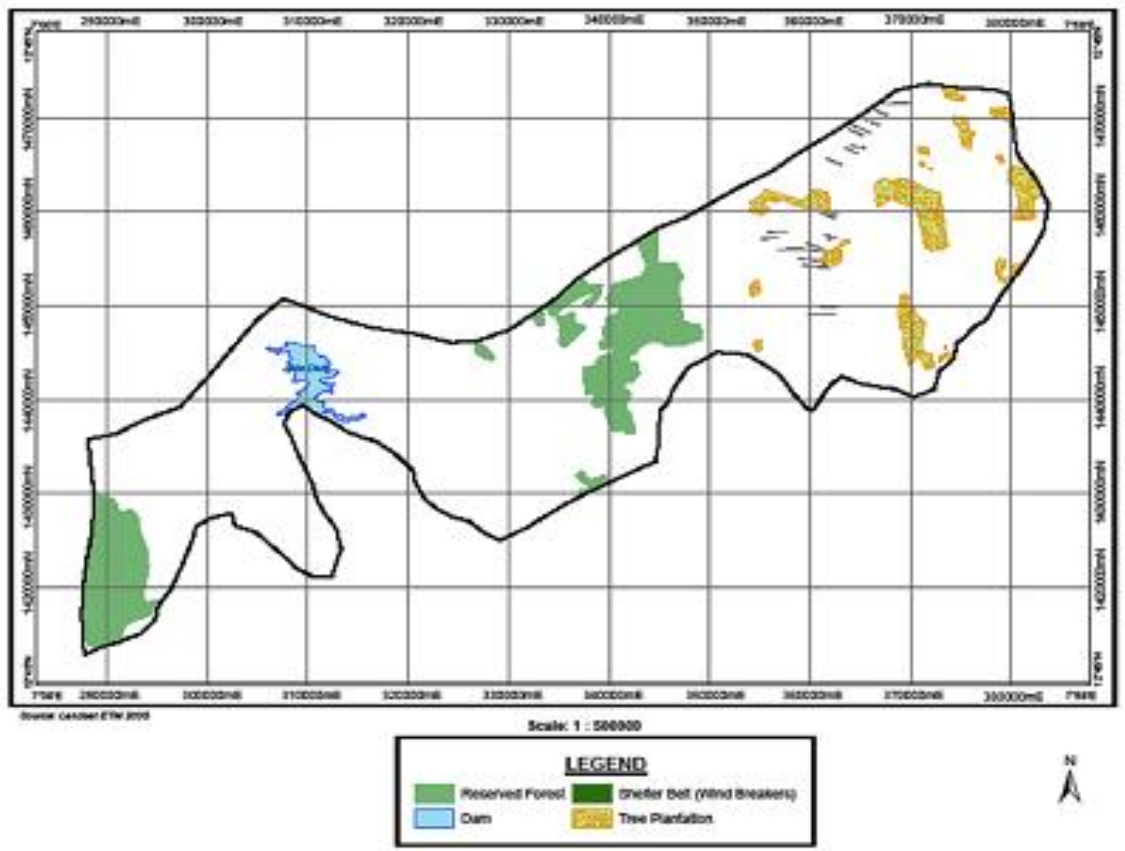

Figure 6. Afforestation in Jabia and Kaita LGA of Kastina State (2006) 
Richard Sunday Thlakma and Omale Eche John/GEOSI Vol 4 No 2 (2019) 124-145

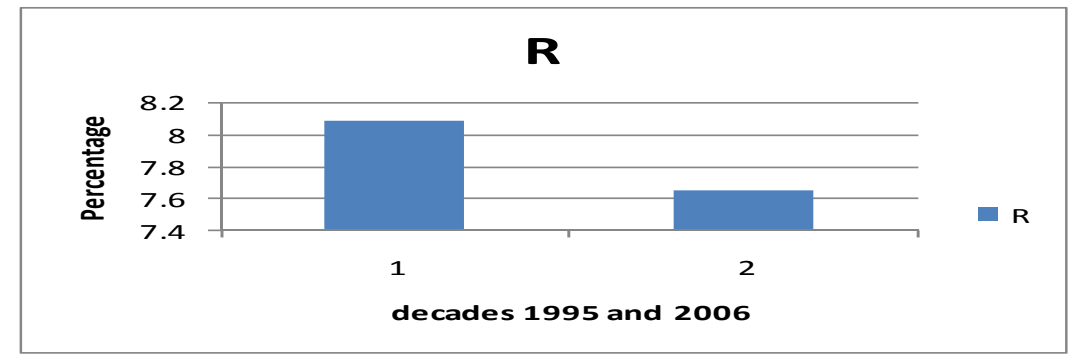

Figure 7. Reservoir Area. 1995 and 2006

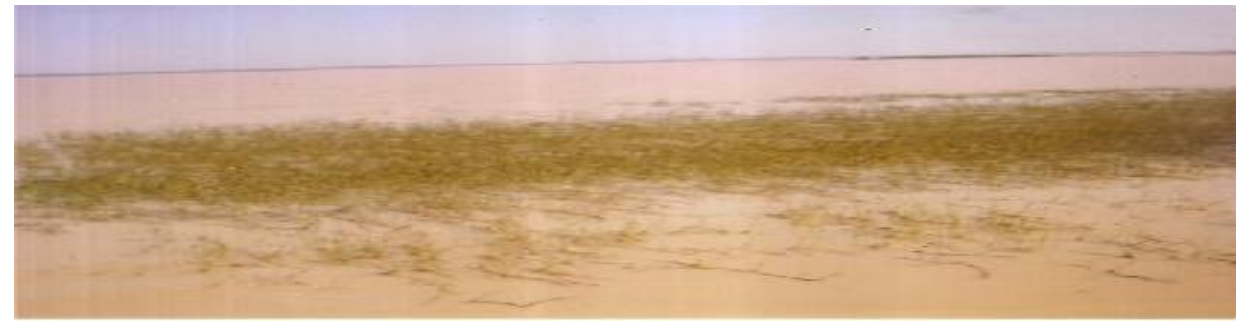

Plate 1. Different views of Jibia Dam which is used for irrigation in Jibia

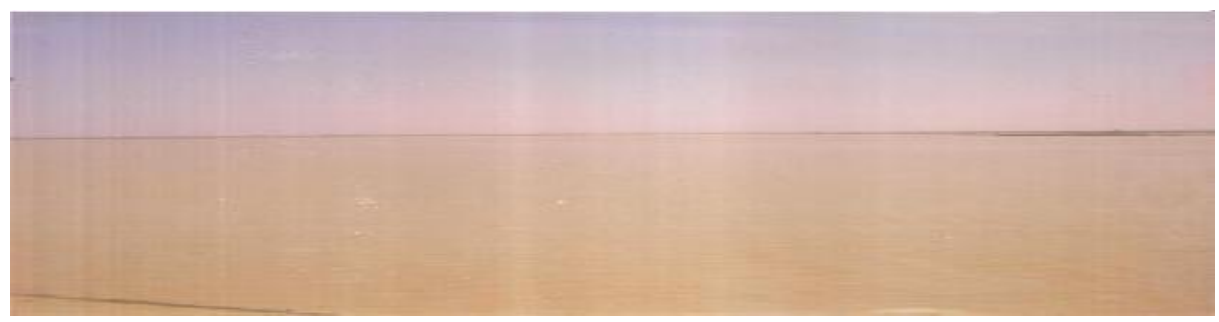

Plate 2. Different views of Jibia Dam which is used for irrigation in Jibia

\subsubsection{Shelter Belts}

The total afforestation area reserved as shelter belt or wind breaker in the study area is small. It declines from $5.91 \%$ in 1987 to $1.097 \%$ in 1995 however, a shot up to $7.39 \%$ in 2006 as it shows in Figure 8, the drop in the area coverage of shelter belt in the second decade result from poor maintenance and human interference.

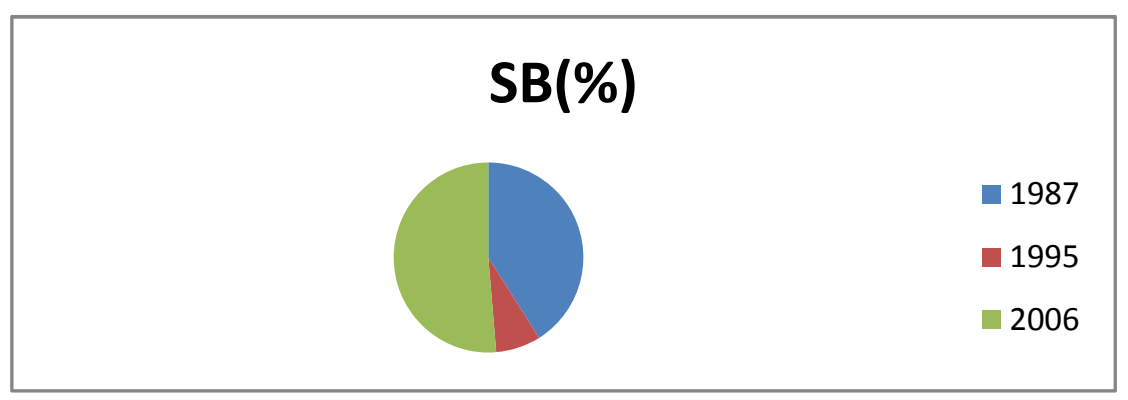

Figure 8: Shelter Belt Area.1987, 1995 and 2006

This evidence is also shown on the vegetal map, of the study area in figures 4, 5 and 6. Figure 3 has no shelter belts on it, this is because shelter belts were not established in the 
first decade of this study. Plates 3, 4, 5 and 6, F show evidence of afforestation in the study area.

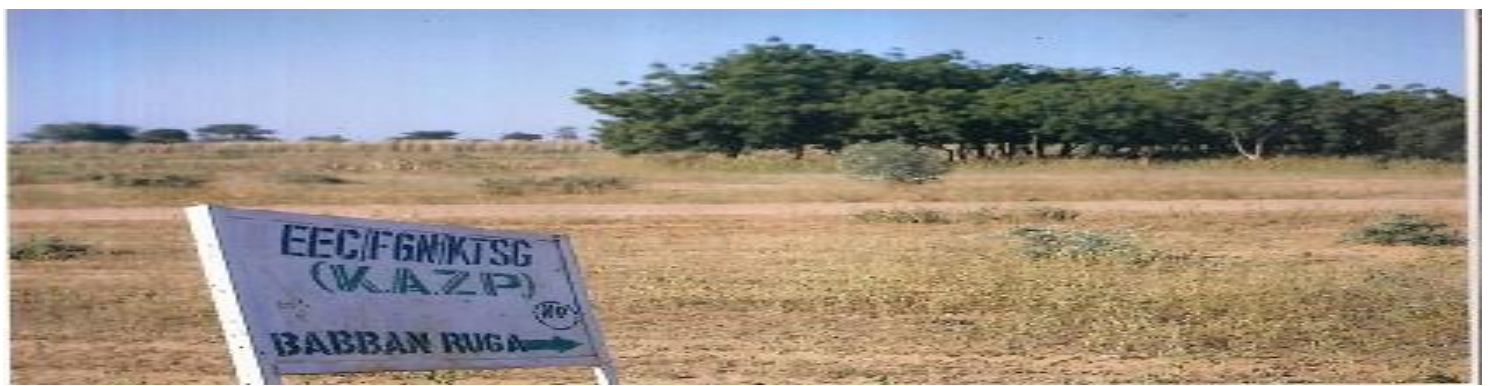

Plate 3. Grass hedging in Kwana Shagari in Kaita Local Government Area of (Evidence of afforestation in the study area)

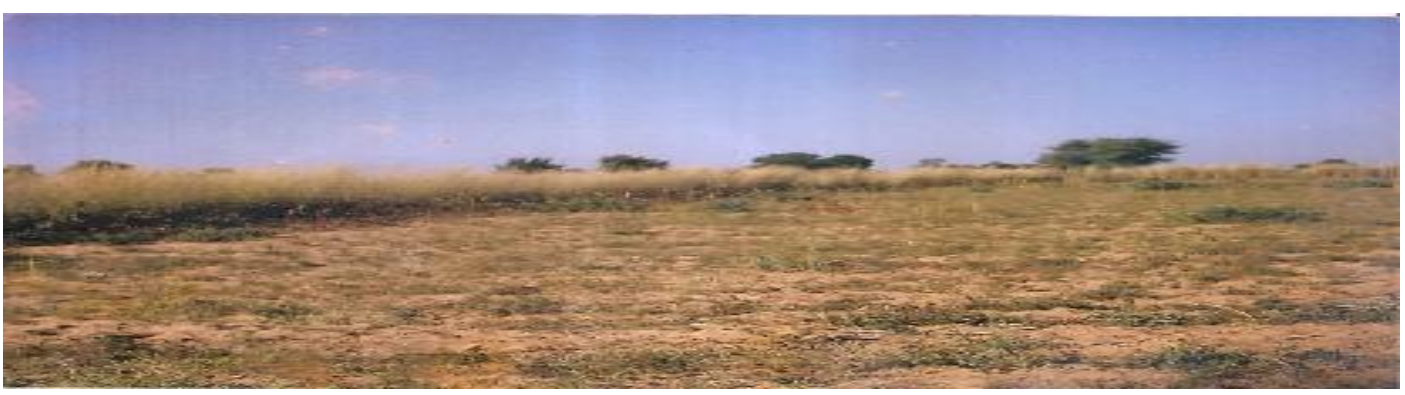

Plate 4. Grass hedging in Gidan Saidu Buzu in Kaita Local Government Area of (Evidence of afforestation in the study area).

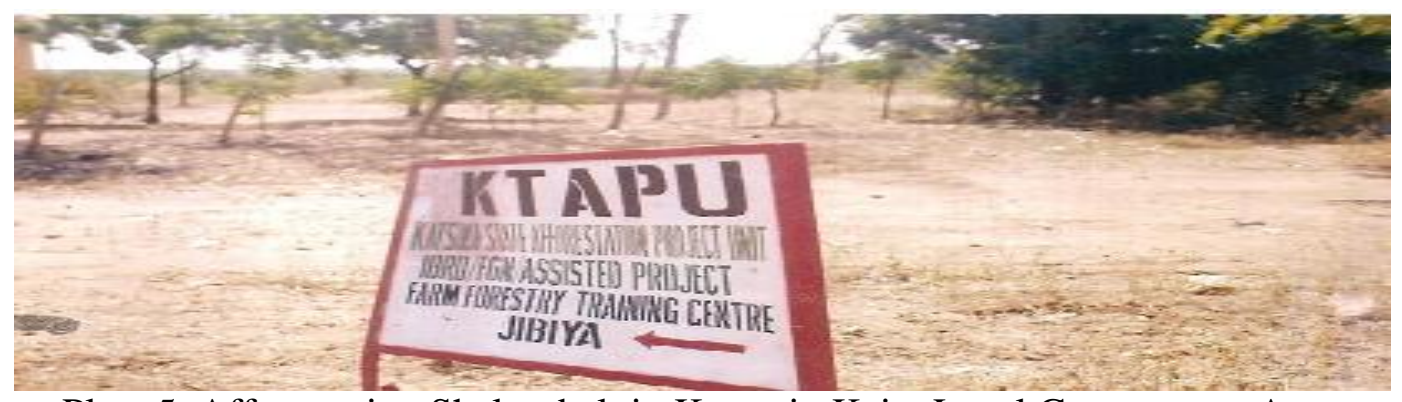

Plate 5. Afforestation Shelter belt in Kurya in Kaita Local Government Area



Plate 6. Afforestation Shelter belt in Magama in Jibia Local Government Area.

3.1.4 Tree Planting: Woodlots, Natural tree Regeneration, Trees on Farmland, Trees on Farm Boundaries etc. 
From the satellite imagery, the data collected to assess tree planting as a strategy to combat desertification shows a decreasing trend in the effort towards tree planting, all through the sampled period. The decline in tree planting may be attributed to poor maintenance of the seedlings to maturity and also human interference and animals browsing.

\subsection{Determination of The Success Rate of Various Strategies Used For Combating Desertification In The Study Area}

The third objective of the study is to determine the success rate of the various strategies used in combating desertification in the study area. From the literature, the following strategies were identified: the use of water dams for irrigation purposes, establishment of shelter belts, woodlots, wind breaks, trees on farm lands, natural tree regeneration and the planting of vertiver grasses for sand dune stabilisation. For the study area 60 questionnaires were issued to selected respondents. From the frequency analysis, a 100 percent response rate was recorded. This was because of the interest of the respondents on the issue of desertification.

When asked if they knew what desertification was, all the respondents said yes. The frequency Table is also shown Table 3.

Table 3. Knowledge of the term desertification in the study LGAs

\begin{tabular}{cccc}
\hline Frequency & Percent & Valid percent & Cumulative percent \\
\hline 60 & 100.0 & 100.0 & 100.0 \\
\hline
\end{tabular}

Source: Author's Analysis

\subsubsection{Effects of Desertification in the Study Area}

They were further asked what effects they would associate with desertification, $33.3 \%$ said that it makes productive lands to become unproductive; $10 \%$ said it covers roads with sand; another $10 \%$ said it makes agricultural land to become unproductive; yet another $10 \%$ said it bring sand to cover their houses, and $36.7 \%$ said it leads to the disappearance of trees. The frequency Table is shown in Table 4. Despite the much efforts put in place by various organisations to reduce desertification, there are still some areas where desertification is still a problem as shown in plates 7 and 8 . 


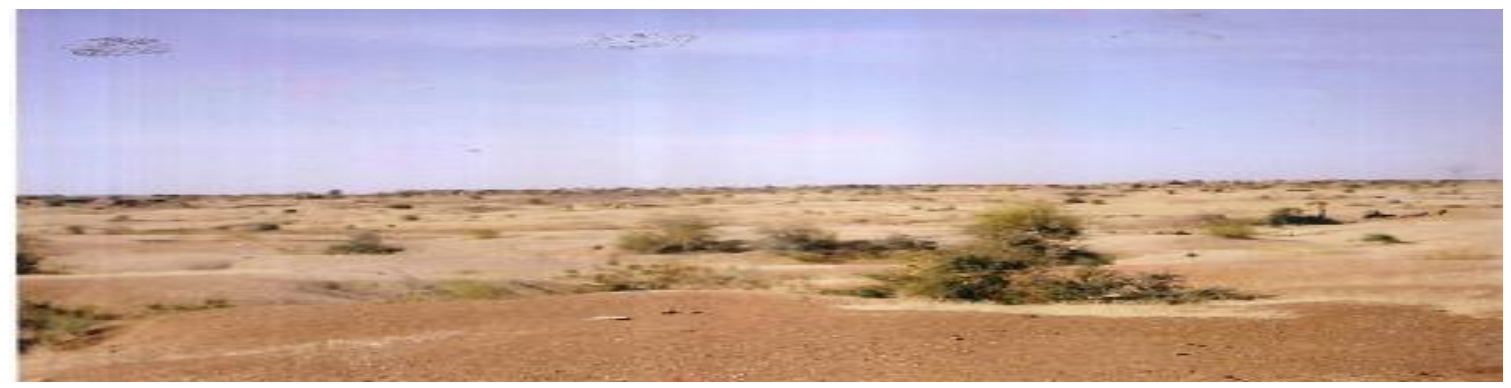

Plate 7. Evidence of desertification in Magama, in Jibia Local Government Area of Katsina State, Nigeria.

Table 4. Effects of desertification in the study LGAs

\begin{tabular}{lcccc}
\hline & Frequency & Percentage & $\begin{array}{c}\text { Valid } \\
\text { Percentage }\end{array}$ & $\begin{array}{c}\text { Cumulative } \\
\text { Percentage }\end{array}$ \\
\hline Productive lands become & 20 & 33.3 & 33.3 & 33.3 \\
unproductive & 6 & 10.0 & 10.0 & 43.3 \\
Roads covered by sand & 6 & 10.0 & 10.0 & 53.3 \\
Poor agricultural productivity & 6 & 10.0 & 10.0 & 63.3 \\
Bring sand to home & 22 & 36.7 & 36.7 & 100.0 \\
Trees disappeared & 60 & 100 & 100 & \\
Total & & &
\end{tabular}

Source: Author's Analysis

As to whether there are any organizations responsible for the mitigation of desertification in the study areas, all the respondents said yes. The organizations were stated to include: EEC, KTAPU, local government and state government as displayed in Table 5.

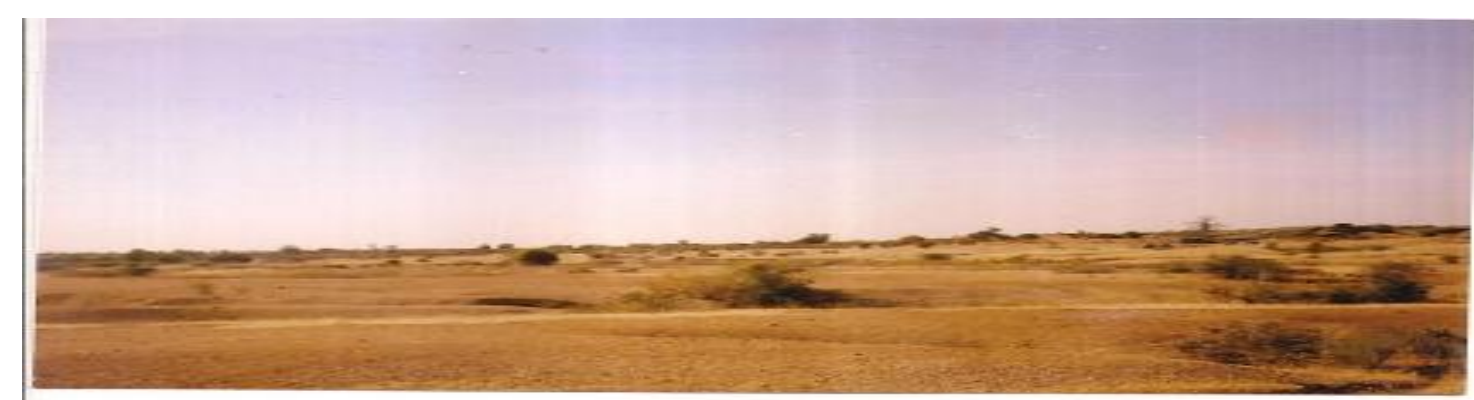

Plate 8. Evidence of desertification in Dankama, in Kaita Local Government Area of Katsina State, Nigeria.

The evidence to prove these are shown on plates 3, 4, display in Table 5 and 6 where various organizations that are involves in curbing desertification in ahead their projects on grounds in the study area. 
Richard Sunday Thlakma and Omale Eche John/GEOSI Vol 4 No 2 (2019) 124-145

Table 5. Organisations involved in mitigating desertification in the study LGAs

\begin{tabular}{ccccc}
\hline & Frequency & Percent & Valid Percent & $\begin{array}{c}\text { Cumulative } \\
\text { Percent }\end{array}$ \\
\hline EEC & 27 & 45.0 & 45.0 & 45.0 \\
State & 2 & 3.3 & 33.3 & 48.3 \\
Government & & 3.3 & 33.3 & 51.7 \\
Local & 2 & 48.3 & 48.3 & 100.0 \\
Government & 29 & 100.0 & 100.0 & \\
KTAPU & 60 & & & \\
Total & & &
\end{tabular}

Source: Author's Analysis.

\subsubsection{Strategies for Combating Desertification}

On the various strategies adopted to combat desertification, $88.3 \%$ said tree planting was the dominant strategy employed e.g woodlots, trees on farmlands and natural tree regeneration. $11.7 \%$ said providing shelter belt (another means of tree planting that also serves as wind breaker) was the other strategy employed. The frequency Table is shown in Table 6.

Table 6. Strategies for combating desertification in the study LGAs

\begin{tabular}{ccccc}
\hline & Frequency & Percent & $\begin{array}{c}\text { Valid } \\
\text { percent }\end{array}$ & $\begin{array}{c}\text { Cumulative } \\
\text { percent }\end{array}$ \\
\hline $\begin{array}{c}\text { Tree Planting e.g woodlots, trees } \\
\text { on boundary }\end{array}$ & 53 & 88.3 & 88.3 & 88.3 \\
Shelter belt & 7 & 11.7 & 11.7 & 100.0 \\
Total & 60 & 100.0 & 100.0 & \\
\hline
\end{tabular}

Source: Author's Analysis.

To determine the success rate of tree planting as a strategy of combating desertification, the respondents were asked to rate the effectiveness of the strategy; $15 \%$ said very effective, $50 \%$ said effective, 30 percent said fairly effective, while $5 \%$ said not effective. The frequency Table is presented in Table 7.

Based on this response it can be said that tree planting as a strategy for combating desertification in the study area is effective. There are also efforts been made on the part of the local government, community members to arrest desertification in the study area. Some the efforts include: campaigning against tree felling, and by tree planting as well. The frequency Table for this response is presented in Table 8. 
Richard Sunday Thlakma and Omale Eche John/GEOSI Vol 4 No 2 (2019) 124-145

Table 7. Effectiveness of the strategies adopted to Combat Desertification in the study LGAs

\begin{tabular}{lcccc}
\hline & Frequency & Percent & Valid Percent & $\begin{array}{c}\text { Cummulative } \\
\text { Percent }\end{array}$ \\
\hline Very Effective & 9 & 15 & 15 & 15 \\
Effective & 30 & 50 & 50 & 65 \\
Fairly Effective & 18 & 30 & 30 & 95 \\
Not Effective & 3 & 5 & 5 & 100 \\
Total & 60 & 100 & 100 & \\
\hline
\end{tabular}

Source: Author's Analysis

Table 8. Community Efforts at Combating Desertification

\begin{tabular}{lcccc}
\hline & Frequency & Percent & Valid Percent & $\begin{array}{c}\text { Cummulative } \\
\text { Percent }\end{array}$ \\
\hline Campaign Against & 27 & 45 & 45 & 45 \\
Tree Planting & 33 & 55 & 55 & 100 \\
Total & 60 & 100 & 100 & \\
\hline
\end{tabular}

Source: Author's Analysis

Though results obtained from questionnaires may not be a very empirical judgment in arriving at the results obtained, which says that the strategies adopted for the mitigation of desertification in the study area are effective. The result obtained from the use of questionnaire corroborated with the empirical findings adopted earlier in the first and the second objectives of the study, it shows that desertification as an environmental problem of the study area has reduced drastically from $43.34 \%$ in 1976 to $1.29 \%$ in 2006 . These findings are scientific in nature; it now substantiates the result obtained from the use of questionnaire.

Personal observation of the researcher, who has lived in study area for close to a decade, also is a proof to substantiate the results obtained from the questionnaires. The observations show that afforestation as a means of curbing desertification, is the major technique adopted in the study area, and it is effective. This evidence is also seen by the various photographs of the projects carried out by various organizations to curb desertification in the study area.

From the evidences provided by the satellite imageries used for the research, and the literature review, the results obtained, and personal observations of the researcher, whom has lived in the area on which this research was carried for a decade. It shows that desertification 
as an environmental problem of that region is gradually been phased out totally. This evidence is from various activities put in place to check desertification in this region. There has been an internationally assisted programme from the World Bank, Katsina Arid Zone Programme which was later called European Economic Community/Katsina State Government, (EEC/KTSG).

Agricultural Development (IFAD). Katsina State Agricultural and Community Development Project (KSACDP).This are all internationally assisted programmes to combat desertification in Katsina state, with the study area inclusive. This evidence also correlated with the (UNCCD, 1997) which called for international cooperation and a partnership approach in checking desertification. It focuses on improving land productivity, application of land conservation and sustainable management of water resources. The Federal Government of Nigeria also plays a very big role in combating desertification in the study area, through the Federal Ministry of Environment, Ecological Fund, Katsina Afforestation Project Unit/Federal Government Assisted, Though KTAPU is now funded by the katsina state government. The establishment of the Jibia dam which has totally erased desertification on its immediate surroundings are some federal government programmes, currently on ground in Katsina state. Their major roles are to check desertification.

These evidences will support the result gotten in this research that shows that desertification has reduced drastically from about (43.34\%) in 1976 to about $1.29 \%$ in 2006 . All these are efforts put in place by the federal government with the study area inclusive, these programmes have aids in reducing desertification in Katsina state drastically. These are practical phenomenon that is observed by the researcher. This relates to the work done by Bala (2003), who reported that various agencies have desertification control projects on ground in Katsina State. These includes the EEC/KTSG, World Bank Assisted Afforestation Project. Katsina Committee on Drought and Desertification Control, Katsina Afforestation Project Unit KTAPU, Katsina State Ministry of Agriculture etc. Their major aim is afforestation and land management to combat the menace of desertification, as an environmental problem.

The mitigation strategies used: Afforestation is the major mitigation strategy used to combat desertification in the study area. This is done through reserved forests, tree planting in the form of woodlots, natural regeneration, trees on farmland shelter belts establishment, Orchards The use of vertiver grasses and trees on farm boundaries. The personal observations of the researcher and the literature reviewed shows that the major mitigation strategies used in the study area by Katsina Afforestation Project Unit, (KTAPU). Katsina Agric and Rural 
Development Authority, (KTARDA). European Economic Community / Katsina State Government,EEC/KTSG. Adopted afforestation as the major mitigation strategy in checking desertification in the study area. The Jibia dam also plays a very important role in checking desertification in the study area. This was supported by findings done by Sani (1996). All the evidences given from the results obtained from the research and personal observations of the researcher has justified the findings which said desertification has reduced drastically in the study area.

\section{Conclusion}

The assessment of the success of the strategies used in combating desertification in the study area revealed that there has been an appreciable effort put in place to mitigate the effects of desertification. The area coverage of desertification determined from the satellite imageries shows that the spread was much at the first decade of the study, with an area coverage of about $43.34 \%$ in 1976 but it shrinked in size overtime to about $1.29 \%$ in 2006 . Afforestation statistics derived from the satellite imageries also shows reserve forest which the area coverage in 1976 was only $2.57 \%$ but increased overtime to $66.53 \%$ in 2006 . The area coverage of shelter belt was $5.91 \%$ in 1987 and 7.39 in 2006. With the evidences given, it can now be considered that desertification in the study area has reduced greatly. Results obtained from this research, shows that the major strategy for checking desertification in the study area is afforestation and the strategies are effective. This research to some extent has proved such notions not to be totally right, especially the Food and Agricultural Organization (FAO) report on desertification in Nigeria which shows that desertification is increasing at an alarming rate of about $0.6 \mathrm{~km}$ into Nigeria but in this case it is reducing drastically.

\section{References}

Ariyo, J.A, Abdullahi, C.J. Stigter, O.Z Onyewotu and I. Musa (2005). Community Participation in Planning Desertification, Control Interventions in Northern Nigeria. Lessons from Kano State. A Paper Presented at the Conference on Prospects and Problems of Agricultural Development in Nigeria, Held in Ahmadu Bello University Zaria. June $29^{\text {th }}-$ July $2^{\text {nd }}, 2005$.

Auwal, U. (2006). An Appraisal of Desertification in Arid Zone of Bauchi State. Unpublished PGDEM thesis Department of Geography, Bayero University Kano.

Babura, D.U. (2001). Desertifucation in Babura Local Government Area. Unpublished PGDEM Thesis. Department of Geography, Bayero University Kano. 
Bala, A. (2003). An Evaluation of Drought Incidence and Hazards in Northern Nigeria. A Paper Presented at a Seminar on the Conservation of the environment. Department of Geography Isa Kaita College of Education, Dutsinma, Katsina State $5^{\text {th }}$ November.

Bins, T. (1990). The Threatening Deserts: Ox Blackwell.

Campbell, D.J (1986). The Prospects For desertification in Kajiado District Kenya, Geg.

Federal Office of Statistics (1999). Annual Abstracts of Statistics: facts and Figures about Nigeria.

Katsina Afforestation Project Unit (2006). A brief on Katsina Afforestation Project Unit (FGN ASSISTED) $1^{\text {st }}$ February, 2006.

Katsina Afforestation Project Unit (2006). Annual Reports on Afforestation Projects.

Katsina Afforestation Project Unit (2009). Annual Reports on Afforestation Project.

Katsina Afforestation Project Unit KTAPU. (2009). A brief on Katsina Afforestation Project Unit (FGN ASSITED) $5^{\text {th }}$ February, 2009.

Katsina Agricultural and Rural Development Authority KTARDA. (2006). Land Management \Unit, Historical Background to soil conservation in Katsina State.

Katsina Arid Zone Programme EEC/KTSG (1995). Soil Conservation Experience, A paper for KSACDP one day Soil conservation Strategy Workshop $14^{\text {th }}$ December, 1995.

Katsina Arid Zone Programme EEC/KTSG. (1995). Historical background of soil conservation efforts in Katsina State.

Msafirri, F. (2009). Involving or not Involving Communities in strategies to combat Desertification and Drought in Kenya.

Murtala S.K. (2003). An Analysis of the problems of desertification in Katsina local government area. An NCE project, Isa kaita College of Education Dutsin Ma, Katsina state.

Nasiru, I.M. (2009). Combating Desertification and Drought in Nigeria. Daily Trust Monday, $25^{\text {th }}$.

National Population Commission (2006). Federal Republic of Nigeria (2009), National Population Commission Official Gazette No2, Abuja $2^{\text {nd }}$ February 2009 Vol 96.

Njeru, J. (2005). Monitoring and Modelling crop growth, water use and production crop growth, water use and production under dry land environment, north west of mount Kenya.

Nyong, A.O. and Kanoroglou, P.S (1999). The Influence of water resources and their locations on rural distribution in north eastern Nigeria. A journal of environmental sciences. 
Owen and Pickering (1997). Global environmental issues. Rutledge and New York.

Sagua, V.O, Enabor, E.E, K.O P.R.O, Ojanuga A.V, Mortimore, M. and Kalu, A.E. (1987). Ecological Disasters in Nigeria. Drought and Desertification Federal Ministry of science and Technology Lagos.

Sani, M. (1996). Evaluation of Desertification and its effects in Jibia local Government area of Katsina state. Unpublished PGDEM Thesis. Department of Geography Bayero University Kano.

Shittu, K. (1999). An Assessment on the socio economic effects of desertification in Katsina state. An Unpublished BSC project Department of Geography Bayero University Kano.

Stebbing, E.P. (1935). The Encroaching Sahara: The Threat to west Africa colonies. A geographical Journal.

The United Nations Convention to Combat Desertification (1997). A new Response an age old problem.

United Nations Conversation on Desertification (1977). Desertification, it Causes and Consequences: Pergmon Press.

United Nations, Department for Public Information (1997). The United Nations convention to combat desertification.

Whates and Jones (1992). Land Degradation. Edward Arnold London. 